\title{
Proceeding
}

Supplementary Issue: Autumn Conferences of Sports Science. Costa Blanca Sports Science Events, 18-19 December 2020. Alicante, Spain.

\section{How can the technology be integrated in Outdoor Movement Education for children and the youth with special needs?}

\author{
ROBERTO COPPOLA ${ }^{1,2} \triangleleft$, PATRIZIA TORTELLA 3 , DANIELE COCO ${ }^{4}$, FRANCESCO SGRÒ ${ }^{1}$ \\ ${ }^{1}$ Faculty of Human and Society Sciences, University of Enna "Kore", Enna, Italy \\ ${ }^{2}$ Faculty of Kinesiology, University of Split, Split, Croatia \\ ${ }^{3}$ Faculty of Educational Sciences, University of Bolzen, Bolzen, Italy \\ ${ }^{4}$ Faculty of Educational Sciences, University "Roma Tre", Rome, Italy
}

\begin{abstract}
The technological innovations of the last decade have caused countless changes to everyone's lifestyle, especially in the number of hours spent in front of a screen. These generational differences are even more marked if the new generations of students are taken into consideration, in fact, even at the school level, technological innovations have brought changes. Just as lifestyle and teaching have changed, what is considered as the "needs" of pupils and how they live and relate both in formal and informal environments have also changed. Considering the emergency period caused by the COVID-19 pandemic, greater attention has been paid to the importance of exercising and everyone has also re-evaluated the beauty and benefits of exercising outdoors. Outdoor Movement Education in this sense can be a key that allows the new generations to experience the emotions and sensations that can be felt during outdoor moving activities. This work is a reflection on how technology can be a tool to increase the benefits in Outdoor Movement Education considering children and youth with special needs. The results of this work have shown how the use of technology in Outdoor Movement Education brings numerous advantages both under the didactic profile (i.e., life skills) and with regard to the cognitive (i.e., attention and concentration), motor (i.e., motor skills, fundamental movement skills) and affective (i.e., enjoyment) domains of learning respectively.

Keywords: Outdoor movement education; Technology; Special needs; School; Children; Youth.
\end{abstract}

Cite this article as:

Coppola, R., Tortella, P., Coco, D., \& Sgrò, F. (2021). How can the technology be integrated in Outdoor Movement Education for children and the youth with special needs?. Journal of Human Sport and Exercise, 16(2proc), S651-S662. doi:https://doi.org/10.14198//hse.2021.16.Proc2.50

Corresponding author. Faculty of Human and Society Sciences, University of Enna "Kore", Cittadella Universitaria, 94100, Enna, Italy. https://orcid.org/0000-0001-7888-2208

E-mail: roberto.coppola@unikore.it

Abstract submitted to: Autumn Conferences of Sports Science. Costa Blanca Sports Science Events, 18-19 December 2020. Alicante, Spain.

JOURNAL OF HUMAN SPORT \& EXERCISE ISSN 1988-5202

(c) Faculty of Education. University of Alicante

doi:10.14198/jhse.2021.16.Proc2.50 


\section{INTRODUCTION}

The Outdoor Education activities refer to a vast area of educational practices whose common denominator is the enhancement of the external environment in its various configurations, taken as an educational environment. Outdoor Education is an integral approach that focuses on improving critical thinking, humannature relationships, and on the world as a whole. It also allows students to learn to recognize and solve problems by developing critical skills (Gilbertson, Bates, Ewert, \& McLaughlin, 2006). In addition to the educational-didactic benefits and critical skills there are plenty of benefits when practicing Outdoor Movement Education activities. Outdoor activities play an important role in the physical health of children, in fact, children particularly move and participate more actively in outdoor than indoor activities (Dewei, 1963). Outdoor Movement Education activities promote the development of motor skills (Dahlgren \& Szczepanski, 1998, 2005; Tortella \& Fumagalli, 2017), improve memory skills (Sczcepanski \& Andersson, 2016) and also increases concentration skills (Wells, 2000). Outdoor Education, even at the most basic level, provides students with primary experiences of nature, which they can see, hear, taste and smell by themselves (Louv, 2008). Furthermore, Outdoor Education seeks a deliberate critical perspective on aspects of contemporary life as they affect people's relationship with nature (Martin \& McCullagh, 2011). Outdoor Education allows students to use all their senses when interacting and exploring their surroundings, and allowing a more active, personal and meaningful way of learning than studying books (Gilbertson, Bates, Ewert, \& McLaughlin, 2006).

This study will be focused on analysing the technologies that can be used in Outdoor Movement Education activities that allow the inclusion of people with disabilities or special needs in general. By special needs we mean different categories of children and students who may have learning difficulties directly linked to their disability or a difficulty in general. these refer to children with visual impairment or hearing impairment, mentally retarded children, orthopaedically handicapped children, children with behaviour disorders, gifted or talented children, and finally children with learning difficulties (Buli-Holmberg \& Jeyaprathaban, 2016). Education that includes the inclusion of people with special needs allows, through specific individual programming, implementation of an educational program aiming to compensate or overcome difficulties encountered by students, and to increase inclusion in school, including all school disciplines and with greater attention to physical education (Cascone, De Cesare, D'Elia, 2020). The term inclusion refers not only to the inclusion of pupils with disabilities in schools, but also to the use of adequate and specific support that allow learning and the enhancement of cognitive and psychomotor skills, active participation and establishing relationship with classmates or peers in general (Garvar-Pinhas \& SchmelkinPedhazur, 1989; Lipsky \& Gartner, 1997).

Scientific literature offers numerous works that analysed the benefits of Outdoor Education both for children with and without disabilities. Integrated outdoor programs, after specific planning, have many benefits for students with severe disabilities (Schleien \& Ray, 1988), including growth in interpersonal relationships, development of greater sensitivity to the needs of others, increased sense of self-efficacy, greater respect for nature, and greater willingness to take risks (McAvoy, Smith, \& Rynders, 2006; Scholl, McAvoy, Rynders, \& Smith, 2003). Outdoor Education activities have a well-recognized impact on people with disabilities, but such activities need to be organized to provide unique experiences in the educational context. Among the best-known benefits for students with disabilities is in the first place the possibility that outdoor movement activities also include discovering and learning from the natural environment, as well as the possibility of creating an interaction with nature and others (i.e., social skills), and the improvement of problem-solving skills (Keller, 1980). 
The Outdoor Movement Education activities in Italy are still scarce and, what is more, the failure to develop Fundamental Movement Skills (FMS) and a real decline in motor skills has been documented in primary schools (Sgrò, Quinto, Platania, \& Lipoma, 2019). This is partly due to the lack of a teacher in the curricular teaching, experienced in teaching physical education, but also to the lack of predisposition of teachers and families, in regards to the extracurricular environment, to accept the risk factor of Outdoor Movement Education activities. Didactic activities, especially regarding mentioned teaching, are the most deficient, but considering the close connection between cognitive and psychomotor development, all the other disciplines are also deficient. Outdoor Education and Outdoor Movement Education activities are used in most European countries as a teaching method, especially with children and young people (Brodin, 2009). Outdoor Education, especially in Scandinavian countries, is exploited for outdoor learning that puts the relationship with nature and "learning by doing" at the centre of the educational project (Sandberg, 2008). Another factor not to be underestimated in an educational-didactic environment is relating to the possibility of connecting theoretical and conceptual knowledge to empirical and experiential knowledge, even though the movement of the body (Dahlgren \& Szczepanski, 2005).

The development of technology has partly contributed to the removal of the younger population from the almost natural relationship that it should have with the nature (Schenetti, Salvatera, \& Rossini, 2015). Several studies have shown various damages that the excessive use of technology has caused, above all, to the youngest, also resulting in decreased movement and the lack of normal development of physical fitness (Fischetti, Cataldi, Di Terlizzi, \& Greco, 2020). These health repercussions can be predicted by the hours spent in front of a screen (i.e., smartphone, games) as shown by the previous studies (Greco, Tambolini, Ambruosi, Fischetti, 2017; Rosen et al., 2014). New generations and their needs have also changed as a result of technological development, but the potentials of using technology in Outdoor Learning Experiences (Veletsianos et al., 2015) are manifold and also concern the hours spent playing video-games that require active participation of players (i.e., exergames). Exergames are a technology increasingly present in international scientific literature (Sgrò \& Lipoma, 2015) and the benefits on its use extend further to the educational environment by integrating physical education programs (Ennis, 2013; Giblin, Collins, \& Button, 2014; Sgrò, 2014; Sgrò \& Lipoma, 2015).

\section{Method}

The aim of the current study is to analyse the possible uses of technology for Outdoor Movement Education activities in the educational environment, considering the difficulties of children with disabilities or, more generally, children with special educational needs. Literature search was carried out from three international databases such as Google Scholar, OCLC WorldCat, and EBSCO Publishing. The keywords used for this research were Technology, Movement, Outdoor Education, Augmented Reality, QR Codes, Virtual Reality, Disability, Disabled and Special Needs. These were searched in titles and abstracts of various scientific contributions and further filters were applied to narrow the results and make them as specific as possible. Regarding keywords not related to specific technologies (i.e., augmented reality, virtual reality and QR codes) and combinations concerning these words, the filters of the working language (English) and the a vailability of the full-size paper were inserted as well. For the combinations concerning mentioned keywords regarding specific technologies, the year of publication of the scientific contribution from 2010 to 2020 was added as a filter.

Results of the research were divided by possibility of the use in formal (i.e., structured context, educational/training institution), informal (i.e., experiential learning, daily life activities) and non-formal (i.e., learning connected to planned activities but not designed as learning) educational context. 


\section{RESULTS}

\section{Formal environment}

Outdoor Education plays an important role in promoting learning outcomes of personal development and with peers and has a fundamental role in the self-assessment of risk and its management by children themselves (Martin \& McCullagh, 2011). Furthermore, Outdoor Education allows students to learn directly from the natural environment (Tatar \& Bağrıyanık, 2012).

Technology may represent a valid support for Outdoor Education and Outdoor Movement Education activities as many devices are within the reach of all children. For example, they can send their position (i.e., GPS coordinates) during a treasure hunt to their teacher / educator who can thus be always informed of their position, even if they are not in the same place (Güdelhöfer, 2016).

Mobile learning has been defined as the use of portable electronic devices that allow students to interact with curricular, pedagogical and social resources in various places (Bolliger, \& Shepherd, 2017; Crompton, 2013; Koole, 2009), as well as in outdoor environments.

A study shows how the use of video games for smartphones in a formal educational environment allows students to be more involved and to improve learning (Huizenga, Admiraal, Akkerman, \& Dam, 2009). The first connection to make when talking about environments defined by Adventure Learning (Miller, Hougham, \& Eitel, 2013) is the one between students and nature or the surrounding environment in general. In these contexts, the use of technology allows the introduction of new opportunities for learning, teaching, participation (Veletsianos et al., 2015) and inclusion. These outdoor Adventure Learning environments allow students to be more involved (Veletsianos et al., 2015) even when they are not the ones who are carrying out a task. For example, in the Go 4 The Summit projects some explorers climbed mountains all over the world while staying in connection with their own classes to teach social studies content (Moos \& Honkomp, 2011). The use of augmented reality (AR) in a formal educational context also has a huge impact, especially on the motivational aspects (Balog \& Pribeanu, 2010). The use of smartphones associated with AR provides the possibility of conscious and engaging experiences that complete the pedagogical process of learning (Laine, Nygren, Dirin, \& Suk, 2016).

The use of QR Codes has been associated with those defined in a study called Green Map that allow to promote the development of critical thinking of the promotion of sustainability, ecosystem and environmental compatibility (Lai, Chang, Wen -Shiane, Fan, \& Wu, 2013). Therefore, by implementing multimedia tools in the learning environment, in this case outdoors, there is an increase in the effectiveness of student learning (Elliot, 2009). In the case of multidisciplinary teaching, a possible use that is also inclusive is also found in the Science Spots AR platform that helps students understand scientific concepts through interaction between real and virtual objects (Laine et al., 2016), and moreover, creating an educational game-based environment has a playful component that favours the motivational aspects.

Among the technologies used in an indoor didactic context, and which could also be used outdoors, is the Google Glass which are glasses equipped with a projection system that transmits images directly to the eye without obstructing the view and allowing to see what surrounds us. They can be used for guided visits to a planetarium and, as a study by Jones and colleagues (2014) shows, they can be a great resource for deaf pupils who, in addition to seeing what is shown to all, receive live video from an interpreter explaining the constellations. If considering possible uses of these glasses for Outdoor Movement Education, it is clear how they can represent a resource for all students with hearing difficulties. Results of another study conducted in 
the school environment show how Google Glasses increase enthusiasm and involvement during activities and how, given the simplicity of using this device, no difficulties have been encountered even with elementary school students who managed to carry out the assigned tasks (Parton, 2017).

\section{Informal and non-formal environments}

The use of technology combined with experiential learning outdoors results in increased interest and participation of both educators and children. This is due to the great versatility and ease of its use (Bolliger \& Shepherd, 2017), and it also allows inclusion providing greater simplicity of communication between children and the environment (Philip \& Razali, 2020). Outdoor Education activities are often associated with activities involving the movement of participants. It is well known that being in an outdoor environment allows children above all to move more by exploring and learning about not only the environment around them, but also about their own bodies. Scientific evidence shows that physically active children are those who have lower risk of developing chronic diseases (Strong et al., 2005). In a recent study, an Outdoor Movement Education activity was proposed to children who, through the use of a pedometer, recorded the activity carried out daily. Furthermore, with the help of educators, they were also able to develop greater awareness of activities performed by calculating the travelled distance and energy consumption (i.e., calories spent) (Finn, Yan, \& Mclnnis, 2018).

The use of technology in Outdoor Education, as highlighted by a recent study, presents some precautions in its use (i.e. being so accustomed to using technological tools that you risk not being able to read a geographical map anymore), but if well conducted and addressed to educational objectives (i.e. learning and development of skills, knowledge and attitudes, development of an ethical sense and also focused on the benefits for the planet) allows to acquire significant amount of information about what surrounds us and also allows sharing experiences with others (Beames, 2017).

Different studies analysed the impact of Outdoor Education on children with disabilities and the benefits found in these works have shown how this type of education reduces undesirable behaviours, increases concentration while doing the assigned tasks (Dyment, \& Bell, 2008; Fiskum \& Jacobsen, 2012c), reduces externalizing behaviour and vitalizes the pupils with internalizing behaviour (Fiskum \& Jacobsen, 2012a; Roe \& Aspinall, 2011). The advantages of Outdoor Education are innumerable and well documented in the scientific literature which is strongly correlated with the increase in physical activity and fitness in children (Foster \& Linney, 2007). One might think that the use of technology in the external environment is harmful or almost extreme with respect to its purposes, but in general people use quite more technological tools at home than outdoors (Zita, 2008).

GPS technology has been defined as "another tool in the orienteering toolbox" as it allows in an increasingly precise way to identify one's position and to move in the surrounding environment, increasing further the appreciation, understanding and knowledge of the natural world of who uses it (Zita, 2008). This technology is widely used in sports and for all ages, being now a technology within everyone's reach and included in widely used technological tools (i.e., smartphone, smartwatch). Another increasingly widespread technology in both educational and marketing contexts is augmented reality (AR). The AR is a technology that allows, being very engaging, to increase the involvement, interest and motivation of children. Being an intuitive technology, it also allows to help understanding more abstract concepts, and by building internal challenges to the activities it favours the predisposition of children to learn. The EduPARK project is a clear example of how augmented reality and the use of smartphone can promote authentic outdoor learning (i.e., study of various animal and plant species) by enhancing available urban spaces (Pombo \& Marques, 2018). Very different and still not widely used in an educational context is Virtual Reality (VR). It is a technology that 
allows the creation of a realistic-looking graphic environment, allowing the user to move in different directions, as well as providing the ability to interact with virtual objects that can be manipulated. Therefore, "virtual reality can offer a natural human-computer interface, providing immersion in a computer-generated environment through the multisensory channels of sight, hearing, touch, smell or taste" (Cardoso \& Lamounier, 2006). This technology has been used to contribute to the development of cognitive processes in children with intellectual disabilities (Vasconcelos et al., 2017). Children with intellectual disabilities experience the "real" world in a different way. VR has been used as a rehabilitation tool allowing children to acquire skills and abilities to become independent in the future, but the results show that there was also a positive response with regard to cognitive and social skills (Standen \& Brown, 2005).

\section{DISCUSSION AND CONCLUSION}

The current study is part of a context that sees a significant technological increase and a real generational change not only as a lifestyle or as changed teaching aspects, but also as the needs of pupils or children (both with and without disabilities) in general. They have a relationship with technology that is sometimes too developed compared to the natural relationship with the nature that is sometimes absent. An often committed mistake, especially in the educational environment, is to consider experiences of past generations trying to make the new generations live the same experiences. However, this is not always feasible, in fact it is not only the technological context that has evolved, but also the way of relating to children has changed, just as their interests have changed at the educational level. The use of technology in an indoor and outdoor educational environment can be a method to involve children more in terms of teaching, self-knowledge and care, and social skills. Movement is essential especially in younger people as the connection between cognitive and psychomotor development is well-known in the scientific literature. In this sense, Outdoor Movement Education plays a fundamental role as being taught to move more outdoors allows the simultaneous stimulation of all senses in an authentic and natural way (Szczepanski \& Andersson, 2016). The Outdoor Movement Education activities allow, through the important experiential factor, to improve social skills and to learn directly not only through personal experience, but also through experience of peers, or others in general (Gilberson, Bates, Ewert, \& McLaughlin, 2006). The results of a study by McAvoy and colleagues (2006) show how Outdoor Education help people with severe cognitive disabilities to develop social skills and to increase the level of participation.

Inclusive Outdoor Education helps children with even severe developmental disabilities to develop recreational skills and levels of social interaction both with and without other children with disabilities (McAvoy \& Schleien, 2001). Outdoor Education can also impact the reduction of stress compared to indoor education. In this sense, a program that includes both environments could be evaluated as the stress accumulated during indoor activities could be released during outdoor activities without losing the basic focus which is the education of the students while continuing to contribute to their learning (Fiskum \& Jacobsen, 2015). In a formal educational environment and also considering the training of support teachers, particular attention is provided by Information and communication technologies (i.e., ICT, TIC). In fact, their use has increased significantly in recent years (Hersh \& Mouroutsou, 2019), considering both smartphone applications (Motiwalla, 2007) and microlearning activities (Hug, 2007), as well as game-based learning (Hersh \& Leporini, 2012). Students can show a particular predisposition for some subjects, as well as they can show difficulties or dislikes (both in the case of students with or without disabilities) for certain disciplines. Through Outdoor Education it is possible to create positive emotions by connecting theoretical aspects to more tangible and real aspects, thus increasing the probability of better understanding of even more abstract concepts (Güdelhöfer, 2016) also improving the mental representation of the space (Notarnicola et al., 2012). By increasing the awareness of how technology helps and assists people with disabilities, in a recent study, a 
term assistive technology service defined all the ways of using technological aids both in formal, informal and non-formal educational environments which at the same time help to assist children with disabilities both in indoor and outdoor environments (Nepo, 2017).

The use of technology in Outdoor Education helps students to develop problem solving skills and spend less time on solving problems (Folkestad \& O'shea, 2011). Furthermore, a study showed how understanding and performance also increase through the use of the outdoors augmented reality (O'Shea \& Folkestad, 2010). Moreover, the interdisciplinarity that can be experienced through outdoor educational paths helps children to learn and to involve those who, through this informal approach, can also develop social skills by interacting with each other (Passarelli, Hall, \& Anderson, 2010). Smartphones, being mobile devices that allow interaction between students and sharing of content, have great potential in supporting learning activities in both formal and informal contexts (Parsons, 2014). There are numerous applications that integrate the augmented reality enhancing a greater involvement of students (Giannakas, Kambourakis, Papasalouros, \& Gritzalis, 2018) even in outdoor environments (Pombo \& Marques, 2018).

With regard to the complexity of movement and its measurement, especially as regards Outdoor Movement Education activities, it is understood how much technological tools can be a possible solution for the evaluation of motor and sports activities as already highlighted in previous studies and for formal educational contexts (Sgrò, Coppola, Pignato, \& Lipoma, 2019; Sgrò, Mango, Pignato, Schembri, Licari, \& Lipoma, 2017; Sgrò, Nicolosi, Schembri, Pavone, \& Lipoma, 2015) and for motor activities in general (Sgrò, Bello, \& Lipoma, 2009). However, the technology can also be used to support Outdoor Education. With devices such as smartphones or tablets children can be guided and involved in a treasure hunt in which they can take pictures and send GPS coordinates so that the teacher or educator knows where they are at all times (Güdelhöfer, 2016). Acquiring images, videos or audios of excursions allows children to bring them back into a formal educational environment such as school, and to report what they have seen (Edforss Fuchs, Arvola, Nyman, \& Szczepanski, 2015). In Outdoor Movement Education, advantages are thus rediscovered in regards to experiential learning as well as the ability to work in a group. Indeed, Gilberson and colleagues (2006) claim that children in this way become students not only for themselves, but for others and for the world in general. The Outdoor Movement Education, with adequate and calibrated technologies, in a formal educational context of physical education helps students, with and without disabilities, not only to develop motor abilities, but also to acquire awareness about their own body and the movement connected to it and to improve selfconfidence and self-assessment and have a more positive motivation for a healthy lifestyle (Adyrkhaev, 2016). Another application that also has a strong potential is Science Spots AR which, being a relatively lowcost technology that can be used by everyone and adaptable to different special educational needs, can be used in Outdoor Movement Education.

Virtual reality, from an Outdoor Movement Education perspective, plays a very different role than the other technologies discussed so far, as by its nature it is much more invasive and not always usable outdoors. It could be integrated into outdoor activities which are focused on movement, for example in some stations built ad hoc in a park, or generally for a path. VR, as documented by international scientific literature, favours the development of students' cognitive processes especially for children with intellectual disabilities who can recognize environments as friendly and not dangerous (Standen \& Brown, 2005). In another study, virtual reality was used as a support tool for literacy activities for children with intellectual disabilities, managing to support the teaching of correct writing and pronunciation of objects from everyday life (Vasconcelos, Lamounier, Malaquias, Miranda, \& Santos, 2017). 
What does the future hold for us? One of the latest innovations concerns the development of humanoid robots (i.e., iCub, I Robots) which are the focus of research on autism spectrum disorders within a rehabilitation facility. Technological development should not be scary, but it should be seen as an opportunity for individuals with special educational needs to be able to live unique and constructive experiences from educational, experiential and inclusive point of view. A common mistake that is made when talking about technology is to think only of its possible negative impacts, but it provides great potential for inclusion to take a step back and to reflect on how useful it can be in certain contexts and situations if well conducted and contextualized. For example, in Outdoor Movement Education activities involving many participants, the greatest risk is that the communication and instructions given by the educator are not perceived and understood by everyone. In this sense, the use of technology, such as augmented reality, allows all participants to acquire information and to process it at their own pace on a one-to-one relationship level (Folkestad \& O'shea, 2011).

If the Outdoor Movement Education is integrated with technological tools, it can represent a key that helps individuals to live and experience in a new way emotions and sensations characterizing outdoor movement activities, by playing an important role in terms of evaluative aspects (i.e. technology used for measurement and evaluation), didactic aspects (i.e. improvement of life skills) and aspects concerning the cognitive domain (i.e. attention and concentration), motor (i.e. motor skills and fundamental movement skills) and affective (i.e. enjoyment) aspects of learning.

\section{AUTHOR CONTRIBUTIONS}

R.C.: Conceptualization, Methodology, Data curation, Writing-Review \& Editing, and Supervision. P.T.: Conceptualization, Investigation, Formal Analysis, Writing-Original Draft Preparation. D.C.: Conceptualization, Methodology, Formal Analysis, Writing-Original Draft Preparation. F.S: Conceptualization, Writing-Review \& Editing, and Supervision. All authors have read and agreed to the published version of the manuscript.

\section{REFERENCES}

Adyrkhaev, S. G. (2016). Modern technology of physical education of disabled students in conditions of inclusive education. Pedagogics, psychology, medical-biological problems of physical training and sports, 20(1), 4-12. https://doi.org/10.15561/18189172.2016.0101

Balog, A., \& Pribeanu, C. (2010). The role of perceived Enjoyment in the students acceptance of an augmented reality teaching platform: A structural equation modeling approach. Studies in Informatics and Control, 19(3), 319-330. https://doi.org/10.24846/v19i3y201011

Beames, S. (2017). Innovation and outdoor education. Journal of Outdoor and Environmental Education, 20(1), 2-6. https://doi.org/10.1007/BF03400997

Bolliger, D. U., \& Shepherd, C. E. (2017). An investigation of mobile technologies and web 2.0 tools use in outdoor education programs. Journal of Outdoor Recreation, Education, and Leadership, 9(2), 181-196. https://doi.org/10.18666/JOREL-2017-V9-12-8228

Brodin, J. (2009). Inclusion through access to outdoor education: Learning in Motion (LIM). Journal of

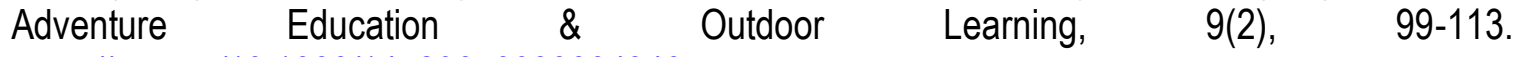
https://doi.org/10.1080/14729670903004340

Buli-Holmberg, J., \& Jeyaprathaban, S. (2016). Effective practice in inclusive and special needs education. International Journal of Special Education, 31(1), 119-134. 
Cardoso, A., \& Lamounier, E. (2006). A realidade virtual na educação e treinamento. Fundamentos e Tecnologia de Realidade Virtual e Aumentada. VIII Pré-Simpósio de Realidade Virtual e Aumentada, Belém, 304-312.

Cascone, C., De Cesare, G.R., D'Elia, F. (2020) Physical education teacher training for disability. Journal of Human Sport and Exercise, 15, pp. S634-S644. https://doi.org/10.14198/ihse.2020.15.Proc3.16

Crompton, H. (2013). A historical overview of m-learning: Toward a learner-centered education. In Z. L. Berge \& L. Y. Muilenberg (Eds.), Handbook of mobile learning (pp. 3-14). New York, NY: Routledge.

Dahlgren, L. O., \& Szczepanski, A. (1998). Outdoor education: Literary education and sensory experience.

Dahlgren, L. O., \& Szczepanski, A. (2005). Outdoor education: Literary education and sensory experience: An attempt at defining the identity of outdoor education. Beijing Company Ltd Beijing China.

Dewey, J. (1986, September). Experience and education. In The Educational Forum (Vol. 50, No. 3, pp. 241-252). Taylor \& Francis Group. https://doi.org/10.1080/00131728609335764

Dyment, J. E., \& Bell, A. C. (2008). 'Our garden is colour blind, inclusive and warm': Reflections on green school grounds and social inclusion. International Journal of Inclusive Education, 12(2), 169-183. https://doi.org/10.1080/13603110600855671

Edforss Fuchs, I., Arvola, M., Nyman, I., \& Szczepanski, A. (2015). Final reporting for the VASS project: The virtual world meets the authentic world in sensuous and integrated learning. Linköping University Electronic Press.

Elliot, S. (2009). Understanding Multimedia Learning: Integrating multimedia in the K-12 classroom. Retrieved on February, 2(7), 2017.

Ennis, C. D. (2013). Implications of exergaming for the physical education curriculum in the 21 st century. Journal of Sport and Health Science, 2(3), 152-157. https://doi.org/10.1016/j.jshs.2013.02.004

Finn, K. E., Yan, Z., \& Mclnnis, K. J. (2018). Promoting physical activity and science learning in an outdoor education program. Journal of Physical Education, Recreation \& Dance, 89(1), 35-39. https://doi.org/10.1080/07303084.2017.1390506

Fiskum, T. A., \& Jacobsen, K. (2012a). Individual differences and possible effects from outdoor education: Long time and short time benefits. World Journal of Education, 2(4), 20-33. https://doi.org/10.5430/wje.v2n4p20

Fiskum, T. A., \& Jacobsen, K. (2012c). Relation between the school environment and the children's behaviour. The Open Educational Journal, 5, 39-51. https://doi.org/10.2174/1874920801205010039

Fiskum, T. A., \& Jacobsen, K. (2015). Children with reading disabilities and outdoor education. International Education Research, 3(4), 1-15. https://doi.org/10.12735/ier.v3i4p01

Folkestad, J., \& O'shea, P. (2011). An Analysis of Engagement in a Combination Indoor/Outdoor Augmented Reality Educational Game. Journal on School Educational Technology, 7(1), 30-37. https://doi.org/10.26634/jsch.7.1.1517

Foster, A., \& Linney, G. (2007). Reconnecting children through outdoor education: A research summary. Toronto, ON: Council of Outdoor Educators.

Garvar-Pinhas, A. \& Schmelkin-Pedhazur, L. (1989). Administrators' and Teachers' Attitudes toward Mainstreaming. RASE: Research and Special Education, 10(4), pp. 38-42. https://doi.org/10.1177/074193258901000407

Giannakas, F., Kambourakis, G., Papasalouros, A., \& Gritzalis, S. (2018). A critical review of 13 years of mobile game-based learning. Educational Technology Research and Development, 66(2), 341-384. https://doi.org/10.1007/s11423-017-9552-z

Giblin, S., Collins, D., Button, C. (2014). Physical literacy: importance, assessment and future directions. Sports Medicine, 44(9), 1177-1184. https://doi.org/10.1007/s40279-014-0205-7 
Gilbertson, K., Bates, T., Ewert, A., \& McLaughlin, T. (2006). Outdoor education: Methods and strategies. Human Kinetics.

Greco, G., Tambolini, R., Ambruosi, P., Fischetti, F. (2017) Negative effects of smartphone use on physical and technical performance of young footballers. Journal of Physical Education and Sport, 17 (4), art. no. 280, pp. 2495-2501

Güdelhöfer, I. (2016). Outdoor Education and the Inclusion of Children with Special Needs: A Case Study from Germany.

Hersh, M. A., \& Leporini, B. (2012). Accessibility and usability of educational games for disabled students. C. Gonzalez, Student Usability in Educational Software and Games: Improving Experiences, IGI Global, 1-40. https://doi.org/10.4018/978-1-4666-1987-6.ch001

Hersh, M., \& Mouroutsou, S. (2019). Learning technology and disability-Overcoming barriers to inclusion: Evidence from a multicountry study. British Journal of Educational Technology, 50(6), 3329-3344. https://doi.org/10.1111/bjet.12737

Hug, T. (2007). Didactics of microlearning: concepts, discourses and examples, „l Waxmann Verlag $\mathrm{GmbH}$.

Huizenga, J., Admiraal, W., Akkerman, S., \& Dam, G. T. (2009). Mobile game-based learning in secondary education: engagement, motivation and learning in a mobile city game. Journal of Computer Assisted Learning, 25(4), 332-344. https://doi.org/10.1111/j.1365-2729.2009.00316.x

Jones, M., Lawler, M. J., Hintz, E., Bench, N., Mangrubang, F., \& Trullender, M. (2014, June). Head mounted displays and deaf children: Facilitating sign language in challenging learning environments. In Proceedings of the 2014 conference on Interaction design and children (pp. 317-320). https://doi.org/10.1145/2593968.2610481

Keller, W. D. (1980). Outdoor education for the handicapped. Focus on Exceptional Children, 12(6), 1 14. https://doi.org/10.17161/foec.v12i6.7154

Koole, M. L. (2009). A model for framing mobile learning. Mobile learning: Transforming the delivery of education and training, 1(2), 25-47.

Lai, H. C., Chang, C. Y., Wen-Shiane, L., Fan, Y. L., \& Wu, Y. T. (2013). The implementation of mobile learning in outdoor education: Application of QR codes. British Journal of Educational Technology, 44(2), E57-E62. https://doi.org/10.1111/j.1467-8535.2012.01343.x

Laine, T. H., Nygren, E., Dirin, A., \& Suk, H. J. (2016). Science Spots AR: a platform for science learning games with augmented reality. Educational Technology Research and Development, 64(3), 507531. https://doi.org/10.1007/s11423-015-9419-0

Lipsky, D. K., \& Gartner, A. (1997). Inclusion and school reform: Transforming America's classrooms. Baltimore: Brookes.

Louv, R. (2008). Last child in the woods: Saving our children from nature-deficit disorder. Algonquin books.

Martin, P., \& McCullagh, J. (2011). Physical education \& outdoor education: Complementary but discrete disciplines. Asia-Pacific Journal of Health, Sport and Physical Education, 2(1), 67-78. https://doi.org/10.1080/18377122.2011.9730344

McAvoy, L., \& Schleien, SJ. (2001). Inclusive outdoor education and environmental interpretation. Taproot, 13(1), 11-16.

McAvoy, L., Smith, J. G., \& Rynders, J. E. (2006). Outdoor adventure programming for individuals with cognitive disabilities who present serious accommodation challenges. Therapeutic Recreation Journal, 40(3), 182.

Miller, B. G., Hougham, R. J., \& Eitel, K. B. (2013). The practical enactment of Adventure Learning: Where will you AL@?.TechTrends, 57(4), 28-33. https://doi.org/10.1007/s11528-013-0674-9 
Moos, D. C., \& Honkomp, B. (2011). Adventure learning: Motivating students in a Minnesota middle school. Journal of research on technology in education, 43(3), 231-252. https://doi.org/10.1080/15391523.2011.10782571

Motiwalla, L. F. (2007). Mobile learning: A framework and evaluation. Computers \& education, 49(3), 581-596. https://doi.org/10.1016/i.compedu.2005.10.011

Nepo, K. (2017, April). The use of technology to improve education. In Child \& Youth Care Forum (Vol. 46, No. 2, pp. 207-221). Springer US. https://doi.org/10.1007/s10566-016-9386-6

Notarnicola, A., Vicenti, G., Fischeti, F., Laricchia, L., Guastamacchia, R., Tafuri, S., Moreti, B. (2012) Improved mental representation of space in beginner orienteers. Perceptual and Motor Skills, 114 (1), pp. 250-260. https://doi.org/10.2466/03.04.11.PMS.114.1.250-260

O'Shea, P., \& Folkestad, J. (2010). Evaluation of the augmented reality project at the School in the Park. Unpublished Manuscript.

Parsons, D. (2014). The future of mobile learning and implications for education and training. Increasing Access, 217.

Parton, B. S. (2017). Glass vision 3D: digital discovery for the deaf. TechTrends, 61(2), 141-146. https://doi.org/10.1007/s11528-016-0090-z

Passarelli, A., Hall, E., \& Anderson, M. (2010). A strengths-based approach to outdoor and adventure education: Possibilities for personal growth. Journal of Experiential Education, 33(2), 120-135. https://doi.org/10.1177/105382591003300203

Philip, E., \& Razali, F. (2020). The Onward Adventure in the New Age: A Systematic Literature Review of the Outdoor Experiential Learning Meets Digital Technology. American Journal of Educational Research, 8(8), 573-580. https://doi.org/10.12691/education-8-8-9

Pombo, L., \& Marques, M. M. (2018). The EduPARK Mobile Augmented Reality Game: Learning Value and Usability. International Association for Development of the Information Society.

Roe, J., \& Aspinall, P. (2011). The restorative outcomes of forest school and conventional school in young people with good and poor behaviour. Urban Forestry \& Urban Greening, 10(3), 205-212. https://doi.org/10.1016/i.ufug.2011.03.003

Rosen, L. D., Lim, A. F., Felt, J., Carrier, L. M., Cheever, N. A., Lara-Ruiz, J. M., ... \& Rokkum, J. (2014). Media and technology use predicts ill-being among children, preteens and teenagers independent of the negative health impacts of exercise and eating habits. Computers in human behavior, 35, 364375. https://doi.org/10.1016/i.chb.2014.01.036

Sandberg, A. (2008). Miljöer för lek, lärande och samspel. Studentlitteratur.

Scholl, K. G., McAvoy, L. H., Rynders, J. E., \& Smith, J. G. (2003). The influence of an inclusive outdoor recreation experience on families that have a child with a disability. Therapeutic Recreation Journal, $37(1), 38$.

Sgrò, F. (2014). Edu-Exergames. Tecnologie per l'educazione motoria: Tecnologie per l'educazione motoria. Milano: Franco Angeli.

Sgrò, F., \& Lipoma, M. (2015). Can An Exergames Training Program Improve The Jump For Height Skill In Childhood. Turkish Online Journal of Educational Technology, Special Issue for INTE 2015, 8996.

Sgrò, F., Bello, L. L., \& Lipoma, M. (2009, May). A networked embedded computing platform for physical activity assessment. In 2009 2nd Conference on Human System Interactions, pp. 146-151, IEEE. https://doi.org/10.1109/HSI.2009.5090970

Sgrò, F., Coppola, R., Pignato, S., \& Lipoma, M. (2019). A systematic review of the use of technologies for the assessment of movement in physical education. Italian Journal of Educational Technology, $27(1), 19-35$. 
Sgrò, F., Mango, P., Pignato, S., Schembri, R., Licari, D., \& Lipoma, M. (2017). Assessing standing long jump developmental levels using an inertial measurement unit. Perceptual and motor skills, 124(1), 21-38. https://doi.org/10.1177/0031512516682649

Sgrò, F., Nicolosi, S., Schembri, R., Pavone, M., \& Lipoma, M. (2015). Assessing vertical jump developmental levels in childhood using a low-cost motion capture approach. Perceptual and motor skills, 120(2), 642-658. https://doi.org/10.2466/10.PMS.120v12x7

Sgrò, F., Quinto, A., Platania, F., \& Lipoma, M. (2019). Assessing the impact of a physical education project based on games approach on the actual motor competence of primary school children. Journal of Physical Education and Sport, 19, 781-786.

Standen, P. J., \& Brown, D. J. (2005). Virtual reality in the rehabilitation of people with intellectual disabilities. Cyberpsychology \& behavior, 8(3), 272-282. https://doi.org/10.1089/cpb.2005.8.272

Strong, W. B., Malina, R. M., Blimkie, C. J., Daniels, S. R., Dishman, R. K., Gutin, B., ... \& Trudeau, F. (2005). Evidence based physical activity for school-age youth. The Journal of pediatrics, 146(6), 732737. https://doi.org/10.1016/i.jpeds.2005.01.055

Szczepanski, A., \& Andersson, P. (2016). Perspectives on place: 15 professors' perceptions of the importance of the place for learning and teaching outdoors.

Tatar, N., \& Bağrıyanık, K. E. (2012). Opinions of Science and Technology Teachers about Outdoor Educatıon. Elementary Education Online, 11(4).

Tortella, P., \& Fumagalli, G. (2017). The effect of teaching methodologies in promoting physical and cognitive development in children. Physical Activity and Educational Achievement: Insights from Exercise Neuroscience, 297. https://doi.org/10.4324/9781315305790-17

Vasconcelos, D. F. P., Lamounier, E., Malaquias, F., Miranda, A., \& Santos, C. (2017). The protocol of a serious game based on Virtual Reality to aid in the literacy of children with Intellectual Disability. Proceedings of SBGames, ISSN, 2179-2259.

Veletsianos, G., Miller, B. G., Eitel, K. B., Eitel, J. U., Hougham, R. J., \& Hansen, D. (2015). Lessons learned from the design and development of technology-enhanced outdoor learning experiences. TechTrends: Linking Research and Practice to Improve Learning, 59(4), 78-86. https://doi.org/10.1007/s11528-015-0874-6

Wells, N. M. (2000). At home with nature: Effects of "greenness" on children's cognitive functioning. Environment and behavior, 32(6), 775-795. https://doi.org/10.1177/00139160021972793

Zita, A. (2008). Technology Works in the Outdoors. Pathways: The Ontario Journal of Outdoor Education, 20(2), 8-10.

\section{(ब) $\odot \Theta$}

This work is licensed under a Attribution-NonCommercial-NoDerivatives 4.0 International (CC BY-NC-ND 4.0). 